\title{
PUBLIC BUS SERVICE AND THE CONCESSION CONTRACT IN ANDALUSIA. EFFECT OF TRANSMISSION
}

\author{
Silvia Sánchez Portales \\ Transportation Management Unit - University of Málaga, Spain \\ Elvira Maeso González \\ Transportation Management Unit - University of Málaga, Spain
}

\begin{abstract}
The Andalusian sector of regular public passenger transport of general use, has been traditionally characterized by being configured by a wide variety of operators of small and medium-scale, where the concession contracts were the only and main economic activity. Over time, new trends have appeared on the market that have led to the evolution of the sector to other models. On the one hand, transformation of the business owner to corporations, and secondly the penetration of large multinational companies which have entered the sector through the acquisition and, on many occasions, absorbing existing concession companies.

This paper analyzes the changes experienced in the concession contracts related to their change of ownership and its impact on the current structure industry. The analysis shows an overview of the regular public transport system travelers utility road in Andalusia.

The results are interesting for the planning and design of new concession contracts, extension approach of the current contracts and general optimization of the system for promotion of a sustainable transport, which satisfies needs of users, respecting the rule of free market.

In short, this paper aims to provide a deeper knowledge of the sector, from the point of view of the operating companies that intergrates it, showing the evolution in existing business structures.
\end{abstract}

Keywords: Public transport, bus service, concession contract, transport company, Andalusia

\section{INTRODUCTION}

An efficient and effective transport is fundamental in current society. Lifestyle has changed due to the influence of new technologies. Uses and customs are different and they considerately affect the sector.

The European Union develops politics of cooperation between member states on transport, and imposing common norms of forced compliance. The target is to obtain an integrated and competitive domestic market.

In this regard, this paper analyses the relation between regular travelers transport by bus in Andalusia and the concession contract that regulates it, about the current structure of concessionaires and their evolution during concession contract period, analyzed from the perspective of business efficiency. 
The importance of the business dimension and the public or private sources of capital is a factor that directly affects the configuration of the sector.

National studies (Balboa la Chica, Mesa Falcon Mendoza \& Suárez, 2014) on the structure of urban public transport companies in Spain show existence of a heterogeneous pattern sector also reflected in the interurban scope.

At a European level, we find an interest in the pursuit of efficiency in managing these companies. Thus in Germany, we find studies comparing the degree of competitiveness of private enterprise versus government owned companies (Augustin \& Walter, 2010), and others seeking the calculation of the technical efficiency of the operating companies by different management models, position the "multi-utility company" as model business efficiency (Scheffler, Hartwig, \& Malina, 2013). However, other authors propose more standardized management models, as Andersen (Andersen, 1992) that commitment to the implementation of the franchise as a way to bring greater competitiveness to the sector.

Moreover, focusing on the area of the Andalusian regular public transport sector of road travellers, we find an interesting parallel in the evolution of the structures business with the system of public transport by bus in Norway (Mathisen \& Solvoll, 2008). The change is happening in the Norwegian sector regarding the introduction of large holding by acquiring companies awarded smaller, it has also been observed in the region of Andalusia. These concessional transmissions have been the main objective of this article.

For the study of the evolution of the corporate structure of the companies up the Andalusian concession system, data have been compiled on 162 concessions contracts and 103 concessionaries from four different information sources: SITRANBUS data base, the Official Gazette of the Andalusian, the Official Bulletin of the Commercial Registry and financial information platform SABI (Iberian System of Balance Analysis).

The paper is structured in four sections. First, it makes a brief presentation on the theoretical framework within which the study focuses. Second, it describes the current situation Andalusian concession system from the perspective of contracts and holding companies. The following section analyzes the process of change of ownership experienced in concession contracts and the various effects in the structure of the Andalusian sector. Finally, the fourth section presents the main conclusions of the study.

\section{CONCESSION SYSTEM IN ANDALUSIA}

\subsection{Concesssions}

The beginnings of the current Andalusian concession system, are placed on the 1997 with the appearance of the first concession contracts regular public transport road in Andalusia, creating a self-coding "VJA-" to designate the granting full membership to the autonomous region.

Some concessions were newly created and others were formed by replacement or recognition of other existing, transferred by the central government and consequence of the assumption of powers following the entry into force of the Statute Andalusian Autonomy (Organic Law 2/2007) and the law of delegation of state to the regions (Organic Law $5 / 1987$ ) regarding the transport under the regulation provided in the Management Act the 
Land Transport (Law 16/1987).

Currently the sector is made up of a wide range of concessions entirely run by Andalusian territory. However, they do not possess the same representativeness.

From the point of view of operative level, the most of sector activity is bounded in few concessions, assuming the rest less significance than $5 \%$ of the total concessional whole.

If we look at the data generated in 2014, and using as parameter compared variable operating passenger kilometres, you get that $56.19 \%$ of total was produced by five concession contracts.

\begin{tabular}{|l|c|}
\hline \multicolumn{1}{|c|}{ Concessions } & $\begin{array}{c}\text { Passenger } \\
\text { kilometres } \\
\text { (rates) }\end{array}$ \\
\hline $\begin{array}{l}\text { VJA-167 Siles-Málaga-Almería, to Córdoba, Granada and Jaén, with } \\
\text { other roads }\end{array}$ & $15.89 \%$ \\
\hline $\begin{array}{l}\text { VJA-092 Málaga-Algeciras with extension to Rincón de la Victoria and } \\
\text { other roads }\end{array}$ & $15.74 \%$ \\
\hline VJA-160 Sevilla and Granada to Antequera, Córdoba and Málaga & $10.52 \%$ \\
\hline VJA-147 Sevilla-Cádiz-Algeciras-Ronda with other-roads & $8.56 \%$ \\
\hline VJA-089 Chipiona-Sevilla-Ronda-Málaga & $5.48 \%$ \\
\hline REST OF CONCESSIONS (rate < 5\%) & $43.81 \%$ \\
\hline
\end{tabular}

Table 1 - Distribution of passenger kilometres concession in 2014

The value shown in the table refers to the set of concessions collected under the OTHER CONCESSIONS name, it consists of the sum of the passenger kilometres generated by concession contracts that have failed individual values above $5 \%$ of the total. This set of sparse representativeness, is composed of a number of 126 concessions.

\subsection{Concessionaries}

In relation to listed companies as holders of concession contracts, sector structure is composed of a wide variety of entities different dimensions, coexisting within the same framework both big business and SMEs.

In response to the same variable previously analyzed for the companies, it is obtained that the $72.94 \%$ of total passenger kilometres have been registered in 2014 was made by six operators, with the remaining $27.06 \%$ of the data spread across 82 different companies. 


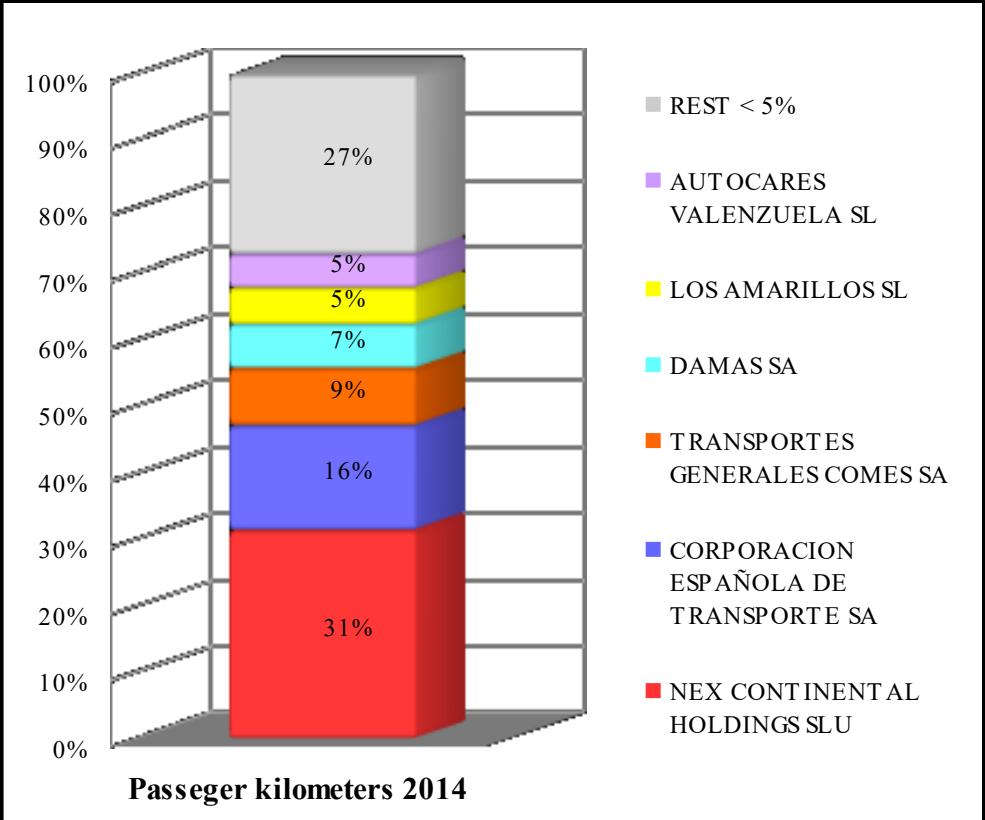

Fig. 1 - Distribution of passenger-km per concession company in 2014

Under the REST $<5 \%$ concept, we have collected the sum of passenger-kilometres made by those companies holding concessions that have generated values less than $5 \%$ of the total studied. This group consists of a set of 82 concessionaries.

\section{TRANSFER OF CONCESSIONS}

\subsection{Modification of concessions}

From the study, it has been observed that over time, some concessional contracts have been altered in content as a result of different processes. On some occasions they have been originated at the request of the Administration and other as a proposal from the operator itself. Mainly there are four types of Processes: unification, transmission, extension and waiver.

Some of these processes generate simple modifications to the conditions contained in the contract, however, others can even cause the extinction of the contract.

\subsection{Characteristics of the transfer in concession contract}

The Article 94 of the Regulations on Land Transport (Royal Decree 1211/1990) provides the possibility of transfering the concessions among natural or legal people.

For its realization it is necessary to comply with the following requirements:

- Prior authorization of the competent authority.

- Perfecting the assignment in deed.

- Demonstration by the acquiring company on its ability to provide service and availability of the applicable media.

- Wait at least three years since inception or previous transfer.

- Existence of a period of at least two years to maturity.

From the set of concessions studied, 52 changes of ownership were analyzed, conducted in 
48 concessions, distributed as follows:

$-92 \%$ of the concessions have had two different owners.

- The remaining $8 \%$ has gone through three or more changes of ownership.

Moreover, the changes found were arranged in three ways mainly:

A. Transfer concession contract itself, emerging as a company owner different.

B. Transfer of the holder of the concession company by acquiring its capital, maintaining the same holder.

C. Transfer of the holder of the concession company by acquiring its capital coupled with a merger or takeover, emerging as distinct entity.

\subsection{Corporate form development at the transfer of concession contract}

In relation to the commodity form of the entities involved in the change process ownership, the following chart has been obtained:

\begin{tabular}{|c|c|c|c|c|c|}
\cline { 2 - 6 } \multicolumn{1}{c|}{} & \multicolumn{2}{c|}{ Receiver company } & SLU & Total \\
\hline $\begin{array}{c}\text { Transferer } \\
\text { company }\end{array}$ & PF & SA & SL & 0 & 11 \\
\hline PF & 0 & 2 & 9 & 6 & 19 \\
\hline SA & 0 & 6 & 7 & 4 & 22 \\
\hline SL & 1 & 7 & 10 & 10 & 52 \\
\hline Total & 1 & 15 & 26 & & \\
\hline
\end{tabular}

Table 2 - Number of concessions with transfer process by type of business entity

Explanation by the Spanish regulation: PF: business owner; SA: Limited company; SL: Limited liability company; SLU: Single-member limited liability company.

Of the transfered concessions, it shows that the greatest number of them corresponds to companies having a commodity form of limited liability company (22 changes) and as for the recipient institutions, they are also limited liability company which staged more changes. The single-member limited liability company modality has been considered by independent to be a common commercial forms in the holding companies. Its main feature is to create groups of companies that are solid business structures. Towards this type of companies there have been 11 changes of ownership.

With regard to the channel used for making the change, the main types of processes used are shown in the following chart. 


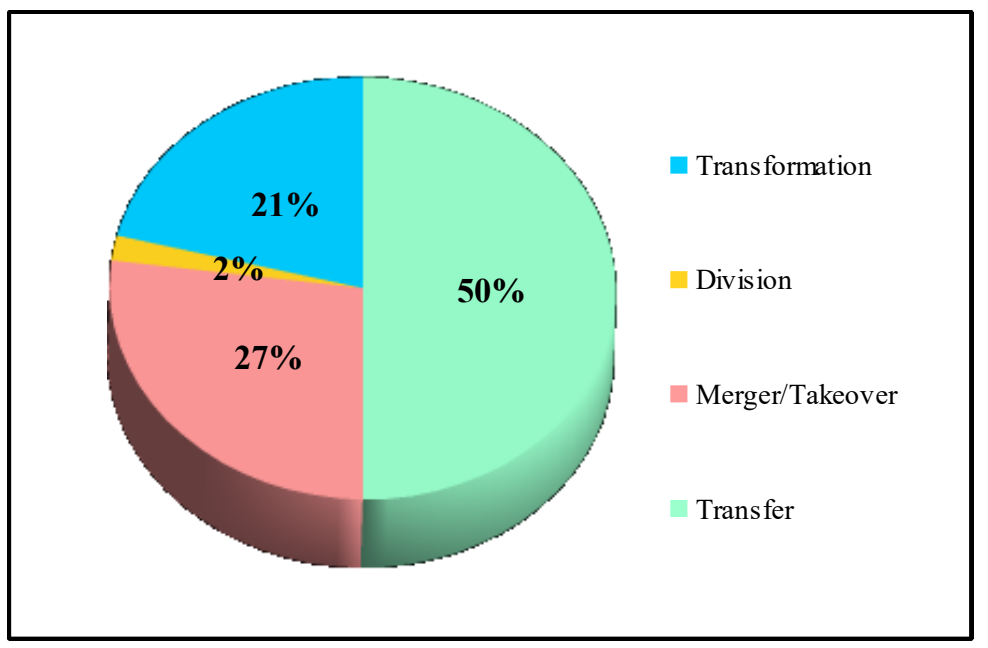

Fig. 2 -Transfer process concessions by type of process used

Half of the changes have been made by the transfer of the concession itself $(50 \%)$. Mergers, and, in many cases combined with a takeover process, have channeled $27 \%$ of the changes. Finally, as a comment on the figure of the individual business owner, it evolves and transforms the business in society looking for new formulas financing and increased growth. This situation has been collected in $19 \%$ of the changes owned studied.

\subsection{Influence of the concession period on concessions transfer process}

With respect to the period since the award of the concession contract facing the change of ownership, it is shown in the following scatter plot the distribution of the number of concessions and the years until the time of change.

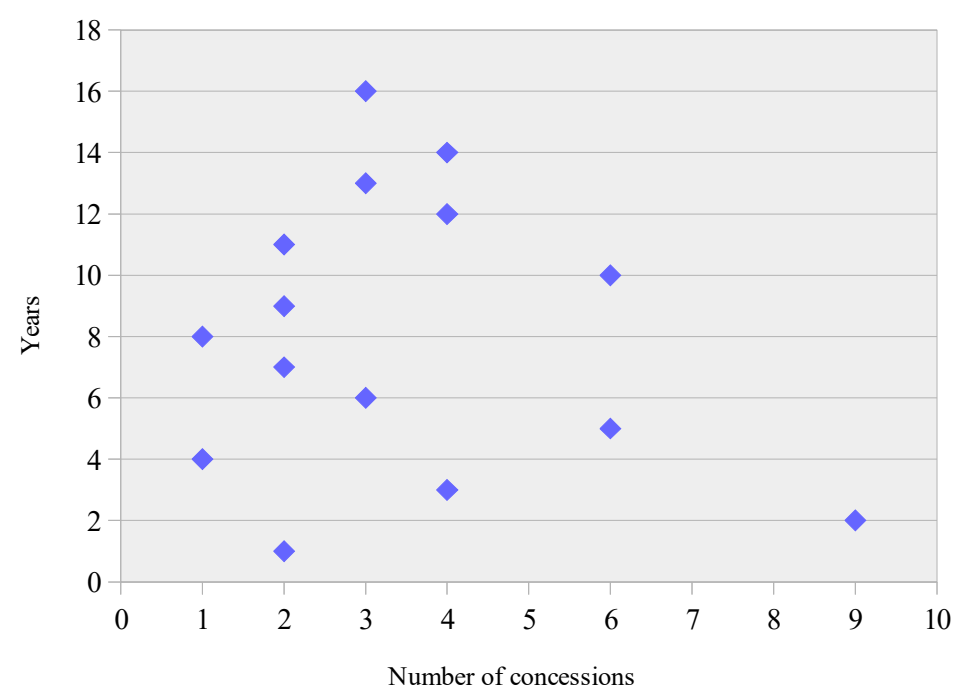

Fig. 3 - Distribution graph of transfer process concessions respect to the period elapsed 
The resulting point cloud has a certain concentration between 3 and 4 concessions with transfer process as the number of years increases.

As isolated within the diagram value, the concessions that made changes within two years of the award are shown, which represent $16.98 \%$ of the total concessions affected by changes in ownership.

\subsection{Effect of transfer process concessions respect to the number of concessionaries}

If we compare the number of concessions that have changed ownership regarding companies currently listed as holders, we can see that distribution shown in the graph below:

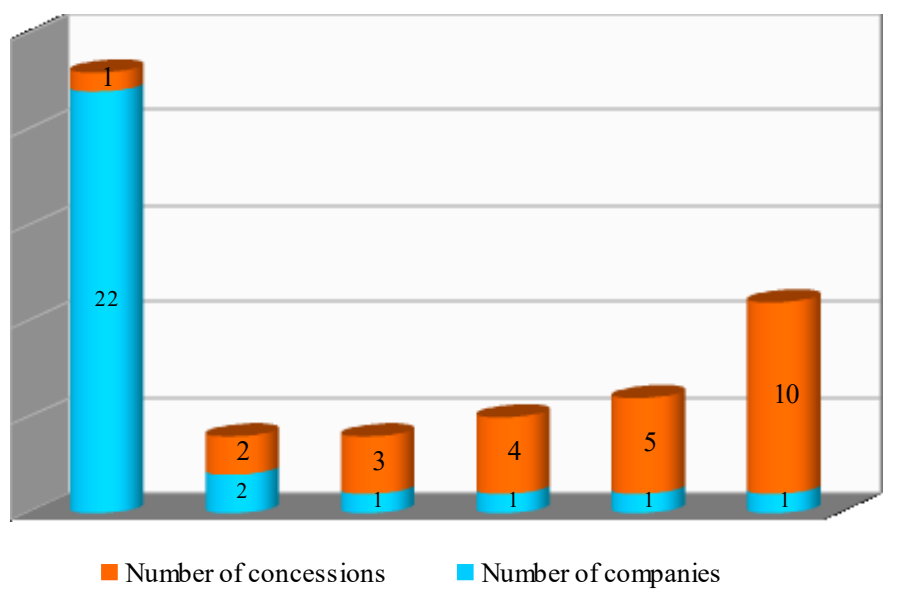

Fig. 4 - Distribution of transfer process concessions respect to current concessionaire

Of all the companies involved, only one entity assumes the most concessional contracts undergoing by process transfer, acquiring a total of 10 concessions.

The other end of the comparison is divided among a variety of companies (22 companies) that have acquired a single concession contract.

\section{CONCLUSIONS}

The processes analyzed have shown unbalanced structure of the concession system of bus public transport in Andalusia.

The system is organized around a few companies leading concessions with greater weight, carrying out change of ownership process that allows them to absorb higher share in the concession system. In the opposite end, there are a large number of companies owning concessions with little representation compared to operating data. These companies have been influenced by the change processes of ownership in two different ways:

- Positive: growth towards a stronger business structure (e.g. transformation from business owner to Limited company).

- Negative: immersion in mergers / absorption with stronger companies that leads to their disappearance. 
On the other hand, it has been detected the existence of concessions that have been changes of ownership in favour of companies in which they have found links with other entities, either in the same industry or belong to different sectors of activity.

From The extracted data, it is clearly seen the influence of business groups in the accumulation of concession contracts, and they are formed for companies transport sector in most.

\section{REFERENCES}

ANDERSEN, B. (1992): "Factors affecting european privatization and deregulation policies in local public transport: the evidence from scandinavia". ScienceDirect, Vol. 26 2, pp. 179-191.

AUGUSTIN, K. y WALTER, M. (2010): "Operator changes through competitive tendering: Empirical evidence from German local bus transport". Research in Transportation Economics, 29, 1, pp. 36-44.

BALBOA LA CHICA, P.M.; MESA MENDOZA, M. y SUÁREZ FALCÓN, H. (2014):

"Análisis de las empresas concesionarias del servicio público de transporte urbano colectivo en España (2008-2010)". Investigaciones Europeas de Direccion y Economia de la Empresa, Vol. 20 - 1, pp. 23-32.

LEY 16/1987 de 30 de julio, de Ordenación de los Transportes Terrestres. (BOE núm. 182, 31 de julio de 1987, pp. 23451-23481).

LEY ORGÁNICA 5/1987 de 30 de julio, de delegación de facultades del estado en las comunidades autónomas en relación con los transportes por carretera y por cable. (BOE núm. 182, 31 de julio de 1987, pp. 23446-23449).

LEY ORGÁNICA 2/2007 de 19 de marzo, de reforma del Estatuto de Autonomía para Andalucía. (BOE núm. 68, 20 de marzo de 2007, pp. 11871-11909).

MATHISEN, T.A. y SOLVOLL, G. (2008): "Competitive tendering and structural changes: An example from the bus industry". Transport Policy, Vol. 15 - 1, pp. 1-11.

REAL DECRETO 1211/1990 de 28 de septiembre, por el que se aprueba el Reglamento de la Ley de Ordenación de los Transportes Terrestres. (BOE núm. 241, 8 de octubre de 1990, pp. 29406-29473).

SCHEFFLER, R.; HARTWIG, K.H. y MALINA, R. (2013). "The effects of ownership structure, competition, and cross-subsidisation on the efficiency of public bus transport empirical evidence from Germany". Journal of Transport Economics and Policy, Vol. 47, Parts 3, pp. 371-386. 